AL IBTIDA: JURNAL PENDIDIKAN GURU MI (2021) Vol 8 (2) : 263-275

DOI: http://dx.doi.org/ 10.24235/al.ibtida.snj.v8i2.8606

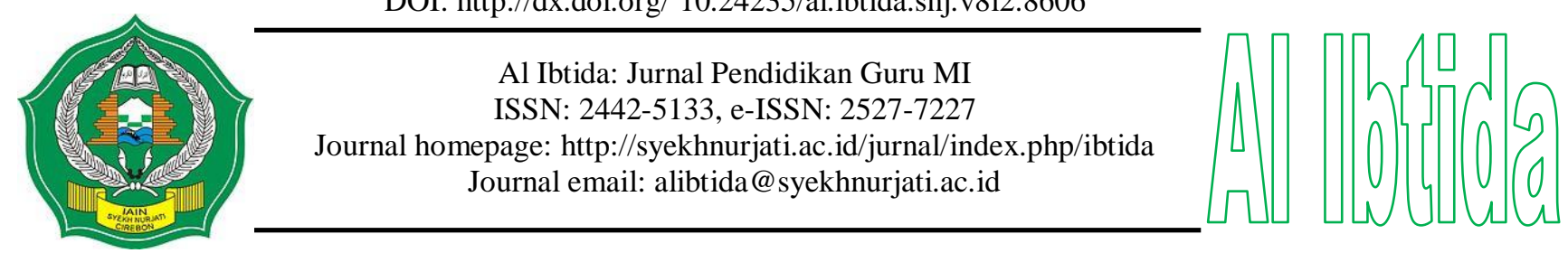

\title{
The Behaviorally Based Intervention Approach to Improve Self- Efficacy of Students' with Attention Deficit Hyperactive Disorder in Elementary School
}

\author{
Abdul Sholeh* \\ *Department of Elementary School Teacher Education, Faculty of Education and Teacher Training, \\ Universitas Nahdlatul Ulama Cirebon, Indonesia \\ Email: abdulsholeh032@gmail.com \\ Asep Supena** \\ **Basic Education Department, Graduate School Program, \\ Universitas Negeri Jakarta, Indonesia \\ Email: asupena@unj.ac.id

\begin{abstract}
Ahmad Arifuddin***
***Department of Madrasah Ibtidaiyah Teacher Education, Faculty of Tarbiyah and Teacher Training, Institut Agama Islam Negeri Syekh Nurjati Cirebon, Indonesia

Email: arifuddin@ syekhnurjati.ac.id
\end{abstract}

Received: June $26^{\text {th }}, 2021$. Accepted: October $18^{\text {th }}, 2021$. Published: October $30^{\text {th }}, 2021$.

\begin{abstract}
This research is motivated by the low self-efficacy of elementary school students with Attention Deficit Hyperactivity Disorder (ADHD) that impact on their academic failure. This study aims to describe the behaviorally based intervention approach in improving the self-efficacy of ADHD students in elementary school. This case study involved five students of an elementary school in Cirebon city. The data were gathered via observations, interviews, and documentation and then analyzed using the descriptive qualitative technique. The results showed that the use of a behavior-based intervention approach could enhance the students' self-efficacy in the aspects of academic achievement, adjustment, social relations, and selfassessment. Therefore, the behavior-based intervention approach can be used as an alternative in increasing the self-efficacy of students with ADHD.
\end{abstract}

Keywords: behaviorally based intervention approach, self-efficacy, attention deficit hyperactivity disorder. 


\begin{abstract}
Abstrak
Penelitian ini dilatarbelakangi oleh rendahnya efikasi diri siswa sekolah dasar dengan Attention Deficit Hyperactivity Disorder (ADHD) yang berdampak pada kegagalan akademik mereka. Penelitian ini bertujuan untuk mendeskripsikan pendekatan intervensi berbasis perilaku dalam meningkatkan efikasi diri siswa ADHD di sekolah dasar. Studi kasus ini melibatkan 5 siswa sekolah dasar di kota Cirebon. Data dikumpulkan melalui observasi, wawancara, dan dokumentasi dan kemudian dianalisis dengan teknik analisis deskriptif kualitatif. Hasil penelitian menunjukkan bahwa penggunaan pendekatan intervensi berbasis perilaku dapat meningkatkan efikasi diri siswa, baik pada aspek prestasi akademik, aspek penyesuaian diri, aspek hubungan sosial, maupun aspek penilaian diri. Untuk itu, pendekatan intervensi berbasis perilaku dapat menjadi alternatif dalam meningkatkan efikasi diri siswa ADHD.

Kata kunci: pendekatan intervensi berbasis perilaku, efikasi diri, attention deficit hyperactivity disorder.
\end{abstract}

\title{
INTRODUCTION
}

The ages of elementary school students in Indonesia range from 6 to 12 years. At this age, children have a higher level of awareness in regulating and controlling emotions according to social standards (Santrock, 2007). On the other hand, their cognitive development is still at the concrete operational stage; they have not been able to think abstractly like adults (Slavin, 2006). Therefore, to achieve academic goals, the learning process in elementary schools should be able to develop cognitive, affective, and psychomotor aspects of students with diverse potentials and character (Juleha, et al., 2020). In fact, in elementary schools, there are students with attention deficit hyperactivity disorder (ADHD).

ADHD is a disorder that occurs in the brain; the neural development is characterized by hyperactivity and impulsivity that interfere with the functioning and development of the child's brain that remain relative over time (Beam \& Mueller, 2017; Nielsen, 2017; Antshel, Zhang-James, \& Faraone, 2013; Gevensleben et al., 2012). ADHD children have a difficulty in sitting, completing tasks, or paying attention for certain time periods. ADHD is associated with behaviors such as interrupting or harassing others, running around improperly, or using other people's belongings without asking permission (Climie \& Mitchell, 2017).

Children with ADHD are prone to act carelessly, irritable, forget school lessons and homework, have a difficulty in doing tasks at school and at home, have a difficulty in listening and speaking, have difficulty in carrying out some commands, daydreaming, have a lack of patience, and often make noise (Pliszka et al., 2000). The ADHD cases of boys and girls aged 6 to 9 years are higher than adolescents (Karlsson \& Lundström, 2021; Muscott et al., 2009). Thorell et al. (2019) stated that there are 25\% of ADHD children with anxiety or 
phobia disorders and certain learning disabilities, both at home and at school. ADHD often continues into older adults with a prevalence rate of $2.8-3.3 \%$ for individuals aged 55 years and older, with a decrease in their quality of life. If the parents have ADHD, children have a $60 \%$ risk of ADHD. Based on the results of the interview on March 15, 2021 with grade IV teachers of Karanganyar State Elementary School, Cirebon, there were 5 students diagnosed with ADHD (22\%) out of a total of 22 students.

Children with ADHD often undergo academic failure, peer rejection, and loss of selfesteem, which can result in loss of motivation and helplessness of learning; they are not focused, defiant, destructive, tireless, aimlessly clear, and nosy spreader (Karlsson \& Lundström, 2021). They also tend to avoid doing academic tasks. It is similar to the results of the National Long Transition Study-2 (NLTS2) reporting that less than half of students with challenging behaviors received all kinds of behavioral interventions or mental health support in school environments (Beam \& Mueller, 2017). ADHD children often have low selfefficacy and undeveloped learning in primary school such as not being able to complete tasks. ADHD has a severe negative impact on daily life functions such as impaired academic, occupational, and social functions as a consequence of these disorders, associated with the lower quality of life (Thorell et al., 2019).

Self-efficacy is a person's belief in their ability to achieve their goals (Flammer, 2015). Pharmacological therapy is generally used to treat ADHD children with low self-efficacy, but the single therapy is not recommended because in the long run it can lead to addiction and even drug dependence until adulthood (Martin GL, 2008). Self-efficacy can be identified from five components, namely verbal academic, academic mathematics, parental relationships, gender, and different genders (Slavin, 2006). Bandura (2002; 2009) defined self-efficacy as a person's belief in the ability to produce or demonstrate a level of ability in working on exercises that affect events that occur in life. The view of children's self-efficacy is one to assess how confident children are that they can handle the daily situations they may face (Cowen et al., 1991). Efficacy will be positively related to good adjustment or adaptation and negative for problem adjustment indicators (e.g., anxiety, depression, and the use of negative coping strategies.

To overcome the problem of self-efficacy of ADHD children in elementary school, appropriate learning approaches such as Behaviorally Based Interventions are required. Interventions obtained from applied behavioral analysis provide teachers and parents with practical strategies for teaching and living with ADHD children. These methods include positive reinforcement of behavior on tasks, modifying tasks and instructional activities to 
promote success, and systematically teaching self-control (Dunbar et al., 2009; Oliver, Wehby, \& Nelson, 2015).

Behaviorally Based Interventions (henceforth BBI) are defined as interventions, instructional strategies, or teaching programs that have been systematically researched and shown to make a positive difference in children when assessed experimentally (Perry $\&$ Weiss, 2007). Teacher-managed interventions for children with ADHD include restructuring the environment (for example, sitting near teachers and breaking down tasks into small manageable pieces), providing frequent opportunities to actively respond in ongoing instruction, and providing different consequences for a child's behavior (positive reinforcement such as praise and marks for appropriate behavior, ignoring inappropriate behavior, and timing of exit fees or responses to inappropriate behavior (Heesen et al., 2012). For students with ADHD, interventions based on functional off-task behavioral assessments have also proven effective (Whitford et al., 2013). National Long Transition Study-2 (NLTS2) reported that less than half of students with challenging behaviors receive any type of behavioral intervention or mental health support in a school environment (Wagner \& Cameto, 2004). Neef et al. (2005) also stated that invention can be a demonstration so that children with ADHD can learn self-control at any time. The results of further research demonstrate that children with ADHD can learn to follow the rules and describe their own rules of behavior, provided they receive clear instructions and consistent reinforcement.

Studies related to ADHD students have been conducted by several researchers. DuPaul, Dahlstrom-Hakki, Gormley, Fu, Pinho, and Banerjee (2017) investigated the effect of support services on the academic achievement of ADHD students. The results show that support services such as advising, coaching, and tutoring generate significant academic gains. Anastopoulos, King, Besecker, O'Rourke, Bray, and Supple (2020) conducted a study on how to treat ADHD students with cognitive behavioral therapy. The results showed that cognitive behavioral therapy was able to significantly reduce ADHD symptoms, improve executive function, and reduce symptoms of anxiety and depression. Similar research has also been conducted by Solanto and Scheres (2021), the results show that cognitive behavioral therapy is able to reduce symptoms of neglect in ADHD students. Furthermore, Gaastra, Groen, Tucha, and Tucha (2020) investigated the effectiveness of classroom management strategies for ADHD students in primary and secondary schools. The results of the research show that teachers often use antecedent-based classroom management strategies rather than selfregulation-based classroom management strategies. A similar study has also been conducted by Strelow, Dort, Schwinger, and Christiansen (2020), the results show that evidence-based 
classroom management strategies are effective in minimizing ADHD problems in schools. To fill the void in the previous studies, this study focuses on increasing the self-efficacy of ADHD students in elementary schools through the use of a behavior-based intervention approach. This study aims to describe the behaviorally based intervention approach to increase the self-efficacy of ADHD children in elementary school.

\section{METHODS}

This research uses a qualitative approach with a case study method. Case study research makes it possible to investigate specific events, situations or social conditions and to provide insight into the processes that explain how certain events or situations occur. Case studies of individuals, groups, and communities help to show important issues of concern, community social processes in real events, and stakeholder experiences (Hodgetts \& Stolte, 2012). Case studies describe and analyze in depth a constrained system (Merriam \& Tisdell, 2015).

The subjects of this study were grade IV teachers and 5 grade IV ADHD students of the State Elementary School Karanganyar, Cirebon City. Meanwhile, the object of this research was the self-efficacy of ADHD students. Data were collected using interviews, observations, and documentation. Interviews were conducted with teachers and fourth grade students to obtain data about the characters of ADHD students in school. Meanwhile, the direct observations of the object of research were carried out to recognize the management of ADHD students, especially those regarding their academic failure. Meanwhile, the documentation technique was done through a scrutiny of the student achievement documents and the student assignment documents.

The research data were then analyzed using descriptive qualitative analysis. This analysis was used to describe the existence of a problem systematically on all relevant elements that had qualitative characteristics. Meanwhile, the triangulation technique was used to know the validity of the data by extracting data from various data sources. Data analysis was carried out through the description stage, reduction stage, and selection stage. Data analysis was also carried out before extracting data in the field and during data mining in the field.

\section{RESULTS AND DISCUSSION}

Based on the results of interviews with the grade IV teachers, there were 5 ADHD students ( 3 male and 2 female) with symptomatic characteristics such as: 1) easy invulted, not paying attention to detail, having a difficulty in paying attention, not listening and following instructions, starting assignments but immediately distracted, having a difficulty in arranging 
tasks and activities (e.g., messy and irregular work), disliking tasks that require sustained mental effort, often losing things, easily being disturbed, and often forgetful; 2) hyperactivity and impulsiveness, restlessness, running around, up and down, noisy, over-talking, throwing answers, difficulty waiting for a turn, interrupting others, acting without thinking (e.g., starting tasks without reading or listening to instructions), impatience, rushing through tasks, and having difficulty resisting temptation. According to Leung et al. (1994), it can result in loss of motivation and helplessness of learning. Therefore, the ADHD students experience academic failure (Beam \& Mueller, 2017). ADHD students' traits such as academic failure indicate low and undeveloped self-efficacy in primary school learning (Thorell et al., 2019). Therefore, efforts should be made to increase the self-efficacy of students with ADHD.

Furthermore, based on the results of observations, it was found that: 1) the learning approach used does not distinguish between ADHD category students and students who are not categorized as ADHD; 2) the learning steps do not describe any differences between ADHD students and students who are not categorized as ADHD; 3 ) the learning steps are not operational and specifically addressed to ADHD students with low self-efficacy; 4) there is no learning medium in addition to the package book; and 5) there is no specific intervention for ADHD students with low self-efficacy and academic failure.

To increase the low self-efficacy of ADHD students in elementary schools, it is necessary to use a behavior-based intervention approach with criteria using peer mediators, content improvement, self-management, technology integration, and effective teaching behavior (Beam \& Mueller, 2017). There is also a need to instruct children to support appropriate social skills, compliance, self-regulation and engagement (Smith \&Fox, 2003). Direct instruction is conducted through several steps such as: a) monitoring ADHD students physical activities through observing, among others, their limbs, tables, chairs and asking them not to leave his/her place; b) providing special attention to ADHD children through observing them every 5 minutes; c) giving instructions and tasks orally (quiet, medium and loud) and by mentioning their name, and e) interventions and positive behaviors/games of good behavior (Stormont, Reinke, \& Herman, 2011).

The results of teacher interviews with ADHD students with low self-efficacy are shown as follows: Teacher: Is the task done?; Students: Not yet Mrs. (pause 5 minutes); Teacher: Has it been done?; Students: Not finished; Teacher: What is the number that is finished: new 1, difficult Mrs.; Teacher: Which one is difficult, can I help?; Students: everything Mrs.; Teacher: If it is difficult, ask me or your classmates. The teacher then checked the results of their work/assignments with guidance. The teacher spent time to guide the students and 
observe the students' works. Indirect intervention was done by the teacher through giving special assignments to the peers to help ADHD students through reprimanding, helping, holding, and conveying the results of monitors to the teacher.

The results of the observation of the academic aspect of ADHD students with low selfefficacy can be shown in Table 1 below.

Table 1. The Results of Observations on Academic Aspects of ADHD Students with Low Self-Efficacy

\begin{tabular}{llll}
\hline \multirow{2}{*}{ No. } & \multirow{2}{*}{ Academic } & \multicolumn{2}{l}{ Percentage of BBI Approach } \\
\cline { 3 - 4 } & & Before & After \\
\hline 1 & Academic Achievement & $<40 \%$ & $60 \%$ \\
2 & Verbal / Loud Speech & $>70 \%$ & $50 \%$ \\
3 & Verbs/ Medium Speech & $50 \%$ & $50 \%$ \\
4 & Verbs/ Slow Speech & $30 \%$ & $30 \%$ \\
5 & Task Orientation & $<30 \%$ & $50 \%$ \\
\hline
\end{tabular}

Based on Table 1, the percentage of academic achievement before the Behaviorally Based Intervention (BBI) approach was only <40\%. After the BBI approach was implemented, the percentage increased to $60 \%$. This was due to interventions in the form of speech to know the learning process of ADHD students with the low self-efficacy. This was because the task intervention could monitor the ability of students in completing tasks so that it positively impacted on their academic achievement. Before the implementation of the BBI, their speech behavior such as shouting was $>70 \%$. It then decreased to $50 \%$ after the BBI was implemented. In terms of doing the task, before the BBI was implemented, the percentage was only $<30 \%$. It then increased to $50 \%$ after the BBI was implemented. The $20 \%$ improvement was better although it was not yet maximum.

Furthermore, the results of the observation of adjustment aspects of ADHD students with low self-efficacy can be shown in Table 2 below.

Table 2. The Results of Observations on Adjustment Aspects of ADHD Students with Low Self-Efficacy

\begin{tabular}{llll}
\hline \multirow{2}{*}{ No. } & \multirow{2}{*}{ Adjustments at school } & \multicolumn{2}{l}{ Percentage of BBI Approach } \\
\cline { 3 - 4 } & & Before & After \\
\hline 1 & Frustration & $70 \%$ & $<30 \%$ \\
2 & Anxiety & $60 \%$ & $50 \%$ \\
3 & Self-awareness & $<30 \%$ & $80 \%$ \\
4 & Socialization partners & $<40 \%$ & $60 \%$ \\
5 & Overall school adjustment & $<50 \%$ & $>50 \%$ \\
6 & Rule compliance & & $90 \%$ \\
\hline
\end{tabular}

As seen in Table 2, before the BBI was implemented, the percentage in the aspect of frustration was $50 \%$. After the implementation of the BBI, it decreased to $<30 \%$. This was 
due to interventions in the form of speech and touch so that the emotion of ADHD students with low self-efficacy could be controlled. Regarding the aspect of anxiety, before the implementation of the BBI, the percentage was $70 \%$. After the BBI was implemented, the percentage decreased to $50 \%$ (reduced by 20\%). Through the task intervention, the students can be monitored with full of guidance of the teacher when they were anxious in doing the task. In the aspect of socialization partners, before using the BBI, the percentage was $<30 \%$. After the BBI was implemented, the percentage increased to $60 \%$. This was due to teacher interventions that specifically helped ADHD students with low self-efficacy. In the aspect of overall school adjustment, before the implementation of the BBI, the percentage was $<40 \%$. After the BBI was implemented, it increased to 50\%. Regarding the compliance of the rules, before the BBI was implemented, the percentage was 50\%. After using the BBI, the percentage increased to $90 \%$. Its improvement was due to intervention of teachers and students to the ADHD children. Then, the results of observations on the aspect of the relationship can be seen in Table 3 .

Table 3. The Results of Observations on Relationship Aspects of ADHD students with Low Self-Efficacy

\begin{tabular}{llll}
\hline \multirow{2}{*}{ No. } & \multirow{2}{*}{ Friend Relationships } & \multicolumn{2}{l}{ Percentage of BBI Approach } \\
\cline { 3 - 4 } & Refore & After \\
\hline 1 & Realistic control expectation & $45 \%$ & $90 \%$ \\
2 & Support and similar theme & $40 \%$ & $70 \%$ \\
3 & Theme support different types & $30 \%$ & $65 \%$ \\
4 & Social support (school & $45 \%$ & $70 \%$ \\
& residents) & & \\
5 & Social problem (bickering) & $60 \%$ & $<20 \%$ \\
\hline
\end{tabular}

(Indicator taken from Emory L. Cowen, et al., 2010).

As seen in table 3, in the aspect of expectation of self-matching, before BBI was implemented, the percentage was only $45 \%$. After BBI, it increased to $90 \%$. This $45 \%$ increase was due to interventions in the form of speech and touch so that emotion of ADHD students with low self-efficacy can be controlled by teachers and students. In the aspect of support of similar friends, before the BBI, the percentage was only $40 \%$. After the implementation of the BBI, it increased to $70 \%$. This $30 \%$ increase was because the intervention of teachers that allowed children to ask for help and advice if they were wrong. In the aspect of friend support, the percentage was $30 \%$. After the BBI, it increased to $65 \%$. This $35 \%$ increase was because of the intervention of teachers who asked ADHD students with low self-efficacy not to stay away from their friends. Regarding the social support (school residents), the percentage was $45 \%$ before the BBI. After the BBI, it increased to 
$70 \%$. Regarding the aspect of social problems such as fighting, before the implementation of $\mathrm{BBI}$, the percentage was $60 \%$. After BBI, it decreased to $<20 \%$. The decrease was due to intervention from teachers and students in controlling ADHD children.

Last, the results of self-assessment aspects observation of ADHD students with low self-efficacy are shown on the Table 4 below.

Table 4. The Results of Observations on Self-Assessment Aspect of ADHD Students with Low Self-Efficacy

\begin{tabular}{|c|c|c|c|}
\hline \multirow{2}{*}{ No. } & \multirow{2}{*}{ Self-Assessment } & \multicolumn{2}{|c|}{ Percentage of BBI Approach } \\
\hline & & Before & After \\
\hline 1 & School interests & $40 \%$ & $80 \%$ \\
\hline 2 & Uncontrollable events & $55 \%$ & $<10 \%$ \\
\hline 3 & Independence & $<30 \%$ & $>55 \%$ \\
\hline 4 & Mobile learning & $60 \%$ & $<15 \%$ \\
\hline 5 & Not responsive to appropriate guidelines & $<30 \%$ & $>85 \%$ \\
\hline
\end{tabular}

As seen in the Table 4, regarding the aspect of school interests, before the BBI approach was implemented, the percentage was only $40 \%$. After the implementation of BBI, it increased to $80 \%$. The $40 \%$ increase was due to interventions in the form of speech, touch, and attention to ADHD students with low self-efficacy. In the aspect of uncontrollable events, before $\mathrm{BBI}$ the percentage was $55 \%$. After the implementation of $\mathrm{BBI}$, it decreased to $<10 \%$. This was because the intervention of teachers through the speech, asking children who were fighting to take a note and giving them punishment in the teacher room. In the aspect of independence, before BBI the percentage was $<30 \%$. After BBI it increased to $>55 \%$. This was due the intervention of the teacher who asked the other students to help and not stay away from ADHD students with low self-efficacy. In the aspect of using mobile learning, before BBI the percentage was $60 \%$. After BBI it decreased to $<15 \%$. Regarding the aspect of unresponsiveness, before the BBI was implemented, the percentage was $<30 \%$. After the implementation of $\mathrm{BBI}$, the percentage increased to $55 \%$. This was due to intervention from teachers and students in controlling ADHD students.

Based on the findings of the research, it is shown that the BBI conducted by the teacher can increase the self-efficacy of ADHD students. All aspects of self-efficacy have increased, both in terms of academic achievement, adjustment to school, relationships, and aspects of student self-assessment. This is because the teacher a) has used the screening procedures to identify students who are at risk and in need of support; b) instructs children to support appropriate social skills, compliance, self-regulation and engagement; (c) provides instructions to families focused on child development and behavior management; and (d) 
engages in family-centered practices (Hart Bell et al., 2004); (Gundel et al., 2019). The teacher has also intervened the students based on the functional off-task behavioral assessments and it is proven effective (Whitford et al., 2013). The results of further research demonstrate that children with ADHD can learn to follow the rules and describe their own rules of behavior; they receive clear instructions and consistent reinforcement. Intervention of classroom-based behavior in schools can solve class problems in schools (Biederman et al., 2014).

The results of this study are in line with the results of research by DuPaul, DahlstromHakki, Gormley, Fu, Pinho, and Banerjee (2017) which revealed that support services such as providing advice, coaching, and teacher guidance have an impact on improving the academic achievement of ADHD students. As stated in the results of the research by Anastopoulos, King, Besecker, O'Rourke, Bray, and Supple (2020) and Solanto and Scheres (2021) that the cognitive behavioral therapy was also able to significantly reduce symptoms of anxiety and depression of ADHD students

\section{CONCLUSION}

Based on the results and discussion, it can be concluded that the Behaviorally Based Intervention approach can improve the self-efficacy of the ADHD students in elementary school. This approach carried out through direct and indirect intervention so that students can be monitored, guided, and facilitated. Thus, the learning becomes more meaningful and multidirectional between students and teachers, and students with students. The results of this study are expected to be an alternative for teachers in improving the self-efficacy of students with ADHD, especially in elementary school.

\section{REFFERENCES}

American Psychiatric Association. (2013). Diagnostic and statistical manual of mental disorders: DSM-5. Arlington, VA.

Anastopoulos, A. D., King, K. A., Besecker, L. H., O’Rourke, S. R., Bray, A. C., \& Supple, A. J. (2020). Cognitive-behavioral therapy for college students with ADHD: Temporal stability of improvements in functioning following active treatment. Journal of Attention Disorders, 24(6), 863-874.

Antshel, K. M., Zhang-James, Y., \& Faraone, S. V. (2013). The comorbidity of ADHD and autism spectrum disorder. Expert review of neurotherapeutics, 13(10), 1117-1128.

Bandura, A. (2002). Self-efficacy: The exercise of control. New York: W.H. Freeman and Company.

Bandura, A. (2009). Self-efficacy in changing societies. United Kingdom: Cambridge University press.

Beam, H. D., \& Mueller, T. G. (2017). What do educators know, do, and think about behavior? An analysis of special and general educators' knowledge of evidence-based 
behavioral interventions. Preventing School Failure: Alternative Education for Children and Youth, 61(1), 1-13.

Biederman, J., Petty, C., Spencer, T. J., Woodworth, K. Y., Bhide, P., Zhu, J., \& Faraone, S. V. (2014). Is ADHD a risk for posttraumatic stress disorder (PTSD)? Results from a large longitudinal study of referred children with and without ADHD. The World Journal of Biological Psychiatry, 15(1), 49-55.

Bong, M. (2002). Predictive utility of subject-, task-, and problem-specific self-efficacy judgments for immediate and delayed academic performances. The Journal of experimental education, 70(2), 133-162.

Climie, E. A., \& Mitchell, K. (2017). Parent-child relationship and behavior problems in children with ADHD. International Journal of Developmental Disabilities, 63(1), 2735.

Cook, L., Cook, B. G., Landrum, T. J., \& Tankersley, M. (2008). Examining the role of group experimental research in establishing evidenced-based practices. Intervention in School and Clinic, 44(2), 76-82.

Cowen, E. L., Work, W. C., Hightower, A. D., Wyman, P. A., Parker, G. R., \& Lotyczewski, B. S. (1991). Toward the development of a measure of perceived self-efficacy in children. Journal of Clinical Child and Adolescent Psychology, 20(2), 169-178.

Dunbar, S. B., Langberg, J. J., Reilly, C. M., Viswanathan, B., McCarty, F., Culler, S. D., ... \& Weintraub, W. S. (2009). Effect of a psychoeducational intervention on depression, anxiety, and health resource use in implantable cardioverter defibrillator patients. Pacing and clinical electrophysiology, 32(10), 1259-1271.

DuPaul, G. J., Dahlstrom-Hakki, I., Gormley, M. J., Fu, Q., Pinho, T. D., \& Banerjee, M. (2017). College students with ADHD and LD: Effects of support services on academic performance. Learning Disabilities Research \& Practice, 32(4), 246-256.

Falk, A. E., Lee, S. S., \& Chorpita, B. F. (2017). Differential association of youth attentiondeficit/hyperactivity disorder and anxiety with delinquency and aggression. Journal of Clinical Child \& Adolescent Psychology, 46(5), 653-660.

Flammer, C. (2015). Does corporate social responsibility lead to superior financial performance? A regression discontinuity approach. Management Science, 61(11), 2549-2568.

Gaastra, G. F., Groen, Y., Tucha, L., \& Tucha, O. (2020, February). Unknown, unloved? teachers' reported use and effectiveness of classroom management strategies for students with symptoms of ADHD. In Child \& Youth Care Forum (Vol. 49, No. 1, pp. 1-22). Springer US.

Gevensleben, H., Rothenberger, A., Moll, G. H., \& Heinrich, H. (2012). Neurofeedback in children with ADHD: validation and challenges. Expert review of neurotherapeutics, 12(4), 447-460.

Gundel, E., Piro, J. S., Straub, C., \& Smith, K. (2019). Self-efficacy in mixed reality simulations: Implications for preservice teacher education. The Teacher Educator, 54(3), 244-269.

Hart Bell, S., Carr, V. W., Denno, D., Johnson, L. J., \& Phillips, L. R. (2004). Challenging Behaviors in Early Childhood Settings: Creating a Place for All Children. Brookes Publishing Company. PO Box 10624, Baltimore, MD 21285.

Heesen, C., Köpke, S., Kasper, J., Poettgen, J., Tallner, A., Mohr, D. C., \& Gold, S. M. (2012). Behavioral interventions in multiple sclerosis: a biopsychosocial perspective. Expert review of neurotherapeutics, 12(9), 1089-1100.

Hodgetts, D. J., \& Stolte, O. E. E. (2012). Case-based research in community and social psychology: Introduction to the special issue. Journal of Community \& Applied Social Psychology, 22(5), 379-389. 
Humphreys, K. L., Aguirre, V. P., \& Lee, S. S. (2012). Association of anxiety and ODD/CD in children with and without ADHD. Journal of Clinical Child \& Adolescent Psychology, 41(3), 370-377.

Jameson, M. M., \& Fusco, B. R. (2014). Math anxiety, math self-concept, and math selfefficacy in adult learners compared to traditional undergraduate students. Adult Education Quarterly, 64(4), 306-322.

Juleha, S., Sudirman, L. N., Arifuddin, A., \& Gunadi, F. (2021, February). Investigating the Cognitive Development of Slow Learners through Constructivist Geometry Games. In ICONEBS 2020: Proceedings of the First International Conference on Economics, Business and Social Humanities, ICONEBS 2020, November 4-5, 2020, Madiun, Indonesia (p. 21). European Alliance for Innovation.

Karlsson, P., \& Lundström, T. (2021). ADHD and social work with children and adolescents. European Journal of Social Work, 24(1), 151-161.

Leung, A. K. C., Robson, W. L. M., Fagan, J. E., \& Lim, S. H. (1994). Attention-deficit hyperactivity disorder: Getting control of impulsive behavior. Postgraduate medicine, 95(2), 153-160.

Marliana, M., Eka, N. L. P., \& Maemunah, N. (2017). Pengaruh Terapi Musik Klasik terhadap Tingkat Konsentrasi pada Anak Attention Deficit Hyperactive Disorder (ADHD) di Yayasan Bhakti Luhur Malang. Nursing News: Jurnal Ilmiah Keperawatan, 2(1), 65-71

Merriam, S. B., \& Tisdell, E. J. (2015). Qualitative research: A guide to design and implementation. John Wiley \& Sons.

Muscott, H. S., Pomerleau, T., \& Szczesiul, S. (2009). Large-scale implementation of program-wide positive behavioral interventions and supports in early childhood education programs in New Hampshire. NHSA DIALOG, 12(2), 148-169.

Neef, N. A., Bicard, D. F., Endo, S., Coury, D. L., \& Aman, M. G. (2005). Evaluation of pharmacological treatment of impulsivity in children with attention deficit hyperactivity disorder. Journal of Applied Behavior Analysis, 38(2), 135-146.

Nielsen, M. (2017). My ADHD and me: Identifying with and distancing from ADHD. Nordic Psychology, 69(1), 33-46.

Nolan, J. D., \& Filter, K. J. (2012). A function-based classroom behavior intervention using non-contingent reinforcement plus response cost. Education and Treatment of Children, 35(3), 419-430.

Oliver, R. M., Wehby, J. H., \& Nelson, J. R. (2015). Helping teachers maintain classroom management practices using a self-monitoring checklist. Teaching and Teacher Education, 51, 113-120.

Pajares, F. (1996). Self-efficacy beliefs in academic settings. Review of educational research, 66(4), 543-578.

Perry, A., \& Weiss, J. A. (2007). Evidence-based practice in developmental disabilities: What is it and why does it matter? Journal on Developmental Disabilities, 12, 167-171.

Pliszka, S. R., Greenhill, L. L., Crismon, M. L., Sedillo, A., Carlson, C., Conners, C. K.,\& Disorder, H. (2000). The Texas Children's Medication Algorithm Project: report of the Texas Consensus Conference Panel on medication treatment of childhood attentiondeficit/hyperactivity disorder. Part I. Journal of the American Academy of Child \& Adolescent Psychiatry, 39(7), 908-919.

Santrock, J. W. (2007). Child development. New York: McGrow.

Schieltz, K. M., Wacker, D. P., Harding, J. W., Berg, W. K., Lee, J. F., Dalmau, Y. C. P., ... \& Ibrahimović, M. (2011). Indirect effects of functional communication training on nontargeted disruptive behavior. Journal of behavioral education, 20(1), 15-32.

Slavin. (2006). Educational Psychology: Theory and Practice. Boston. Allyn and Bacon 
Smith, B., \& Fox, L. (2003). Systems of service delivery: A synthesis of evidence relevant to young children at risk of or who have challenging behavior. Center for Evidencebased Practice: Young Children with Challenging Behavior. Available: www. challengingbehavior. org.

Solanto, M. V., \& Scheres, A. (2021). Feasibility, acceptability, and effectiveness of a new cognitive-behavioral intervention for college students with ADHD. Journal of Attention Disorders, 25(14), 2068-2082.

Stormont, M., Reinke, W., \& Herman, K. (2011). Teachers' knowledge of evidence-based interventions and available school resources for children with emotional and behavioral problems. Journal of Behavioral Education, 20(2), 138-147.

Strelow, A. E., Dort, M., Schwinger, M., \& Christiansen, H. (2020). Influences on pre-service teachers' intention to use classroom management strategies for students with ADHD: A model analysis. International Journal of Educational Research, 103, 101627.

Thorell, L. B., Holst, Y., \& Sjöwall, D. (2019). Quality of life in older adults with ADHD: links to ADHD symptom levels and executive functioning deficits. Nordic journal of psychiatry, 73(7), 409-416.

Whitford, D. K., Liaupsin, C. J., Umbreit, J., \& Ferro, J. B. (2013). Implementation of a single comprehensive function-based intervention across multiple classrooms for a high school student. Education and Treatment of Children, 36, 147-167.

Wiliam, et all (2017). Exceptional Children an Introduction to Special Education Elevent Edition. The Ohio State University

Witt, J. C., VanDerHeyden, A. M., \& Gilbertson, D. (2004). Troubleshooting behavioral interventions: A systematic process for finding and eliminating problems. School Psychology Review, 33(3), 363-383. 